University of Nebraska - Lincoln

DigitalCommons@University of Nebraska - Lincoln

U.S. Environmental Protection Agency Papers

U.S. Environmental Protection Agency

2012

Tsuji-Trost N-Allylation with Allylic Acetates by Using a

Cellulose-Palladium Catalyst

Buchi Reddy Vaddula

U.S. EPA

Amit Saha

U.S. EPA

Rajender S. Varma

U.S. EPA, varma.rajender@epa.gov

John Leazer

U.S. EPA, Leazer.John@epa.gov

Follow this and additional works at: https://digitalcommons.unl.edu/usepapapers

Reddy Vaddula, Buchi; Saha, Amit; Varma, Rajender S.; and Leazer, John, "Tsuji-Trost N-Allylation with Allylic Acetates by Using a Cellulose-Palladium Catalyst" (2012). U.S. Environmental Protection Agency Papers. 182.

https://digitalcommons.unl.edu/usepapapers/182

This Article is brought to you for free and open access by the U.S. Environmental Protection Agency at DigitalCommons@University of Nebraska - Lincoln. It has been accepted for inclusion in U.S. Environmental Protection Agency Papers by an authorized administrator of DigitalCommons@University of Nebraska - Lincoln. 


\title{
Tsuji-Trost $N$-Allylation with Allylic Acetates by Using a Cellulose-Palladium Catalyst
}

\author{
Buchi Reddy Vaddula, ${ }^{[a]+\ldots]}$ Amit Saha, ${ }^{[a|l|+1}$ Rajender S. Varma, ${ }^{*[a]}$ and John Leazer*[a]
}

Keywords: Allylic compounds / Amines / Allylation / Palladium / Heterogeneous catalysis

Allylic amines were synthesized by a simple procedure using a biodegradable and easily recyclable heterogeneous cellulose-Pd catalyst through $N$-allylation of primary and secondary amines. The scope of this protocol includes aliphatic and benzylamines with substituted and unsubstituted allyl acetates and culminates in high yield syntheses. The highlights of the protocol include a ligand-free reaction, simple workup, and catalyst recyclability.

\section{Introduction}

Allylic compounds such as allylic acetates, allylic alcohols, allylic halides, and allylic carbonates undergo the Tsuji-Trost reaction with various nucleophiles such as phenols, amines, and active methylene compounds in the presence of palladium to generate allylated nucleophiles. ${ }^{[1]}$ The Tsuji-Trost transformation plays an important role in the total synthesis of alkaloids such as strychnine, ${ }^{[2]}$ rosephilin, ${ }^{[3]}$ and $(+)-\gamma$-lycorane ${ }^{[4]}$ and other natural products such as hamigeran B. ${ }^{[5]}$ The preparation of allylamines by $N$-allylation of amines is an important organic transformation, as these compounds are often used in the construction of natural products and amino acids. ${ }^{[6]}$ The $\eta^{3}$-allyl-Pd complex, obtained from allyl acetates, can couple with amines to produce allylamines through a mild and selective synthetic route. ${ }^{[7]}$

At present, nonrenewable petrochemicals are the major source of polymer matrices. In view of this, an alternative ecofriendly polymer support is essential. The use of naturally abundant cellulose as a replacement may well serve the purpose. Studies on the application of cellulose and other bioderived polymers as heterogeneous supports in catalysis proved that these compounds can serve as efficient and cheap alternatives. Cellulose-supported palladium and copper particles have been used to catalyze $\mathrm{C}-\mathrm{C}$ and $\mathrm{C}-\mathrm{N}$ coupling reactions in various organic solvents. ${ }^{[8]}$ Earlier, a cellu-

[a] Sustainable Technology Division, National Risk Management Research Laboratory, U.S. Environmental Protection Agency, 26 West Martin Luther King Drive, MS 443, Cincinnati, OH 45268, USA

Fax: +1-513-569-7677

E-mail: Leazer.John@epa.gov

Varma.Rajender@epa.gov

Homepages: http://www.epa.gov/nrmrl/std/ organic reactions.html

http://www.epa.gov/nrmrl/std/ green_chem_nano.html

[\$] These authors contributed equally to this work.

Supporting information for this article is available on the WWW under http://dx.doi.org/10.1002/ejoc.201201241. lose-supported Pd catalyst was used with a special phosphane ligand, tris(3-sulfophenyl)phosphane trisodium salt (TPPTS), for the $N$-allylation of cinnamyl carbonate with morpholine ${ }^{[9]}$ Recently, we demonstrated the preparation of allyl acetates by a simple and facile Heck-type arylation reaction by using palladium supported on magnetic $\mathrm{Fe}_{3} \mathrm{O}_{4} \cdot{ }^{[10]}$

\section{Results and Discussion}

In view of earlier success with supported palladium and the need to further investigate the application of allyl acetates, there is encouragement to explore benign supports such as cellulose. Thus, there is motivation to establish a more general and ligand-free protocol for $N$-allylation reactions by using a cellulose- $\mathrm{Pd}$ catalyst. $\mathrm{Pd}^{0}$ was immobilized on the surface of cellulose microcrystals by reducing $\mathrm{PdCl}_{2}$ in an aqueous suspension of cellulose with the use of sodium borohydride at room temperature to afford the cellulose-Pd catalyst (Figure 1).

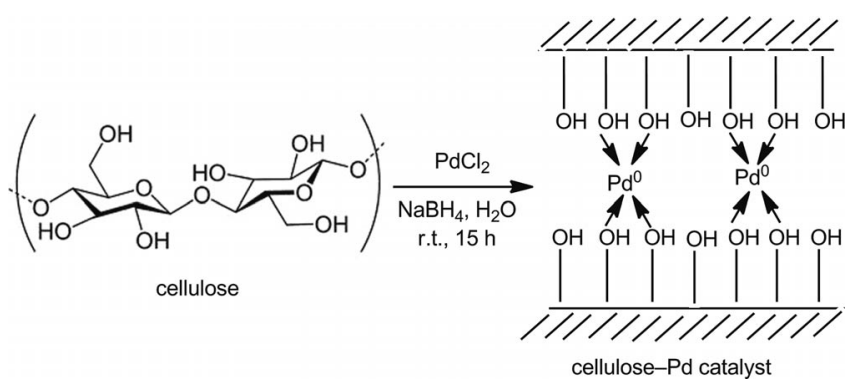

Figure 1. Synthesis of the cellulose-supported Pd catalyst.

Inductively coupled plasma-atomic emission spectroscopy (ICP-AES) analysis showed the weight percentage of Pd to be 9.8. The Pd catalyst was characterized by powder XRD. Immobilization of $\mathrm{Pd}^{0}$ on the cellulose matrix was confirmed by the presence of characteristic $\mathrm{Pd}^{0}$ signals in the spectrum (Figure 2). 

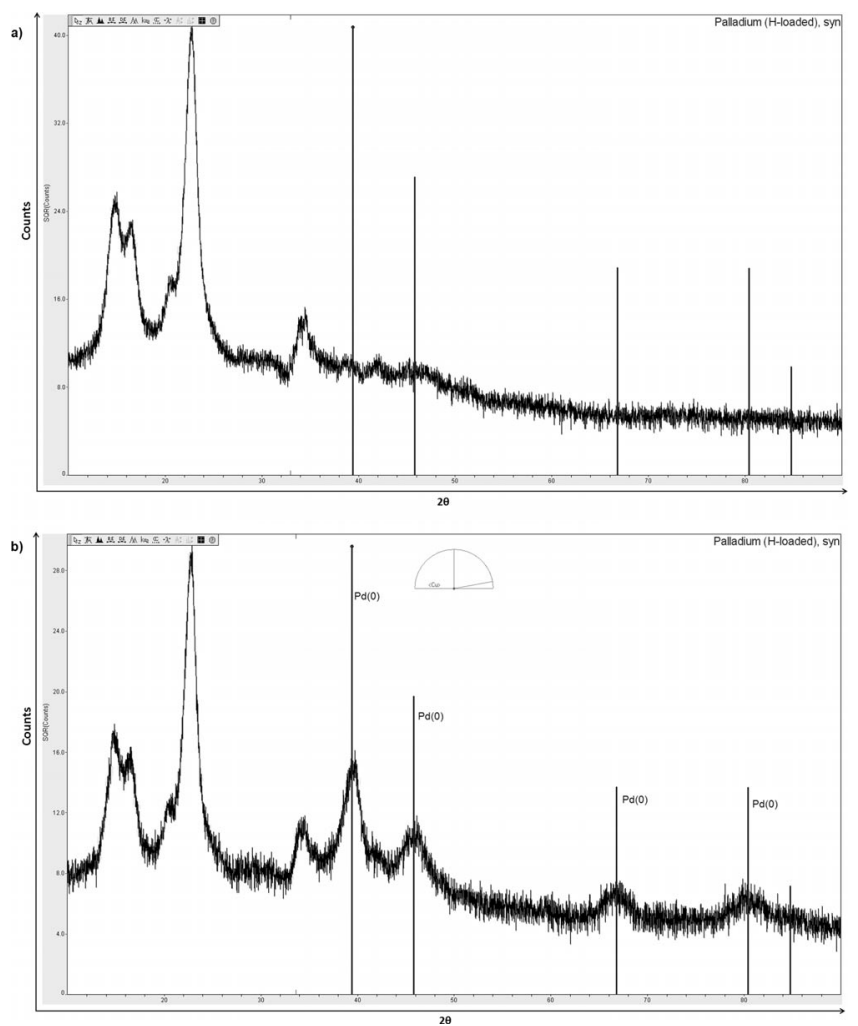

Figure 2. Powder XRD pattern for the (a) blank cellulose support and (b) cellulose-Pd catalyst.

In our continued investigations, we employed the cellulose-Pd catalyst in the $\mathrm{N}$-allylation of amines with allylic acetates in the presence of $\mathrm{K}_{2} \mathrm{CO}_{3}$ as base. In the first attempt, a mixture of piperidine, cinnamyl acetate, $\mathrm{K}_{2} \mathrm{CO}_{3}$, and the Pd catalyst in water was heated at reflux for $12 \mathrm{~h}$. The desired product was not formed, and the full amount of cinnamyl acetate underwent hydrolysis to produce allyl alcohol. To optimize the reaction conditions, a series of experiments was carried out (Table 1).

Table 1. Standardization of reaction condition. ${ }^{[a]}$

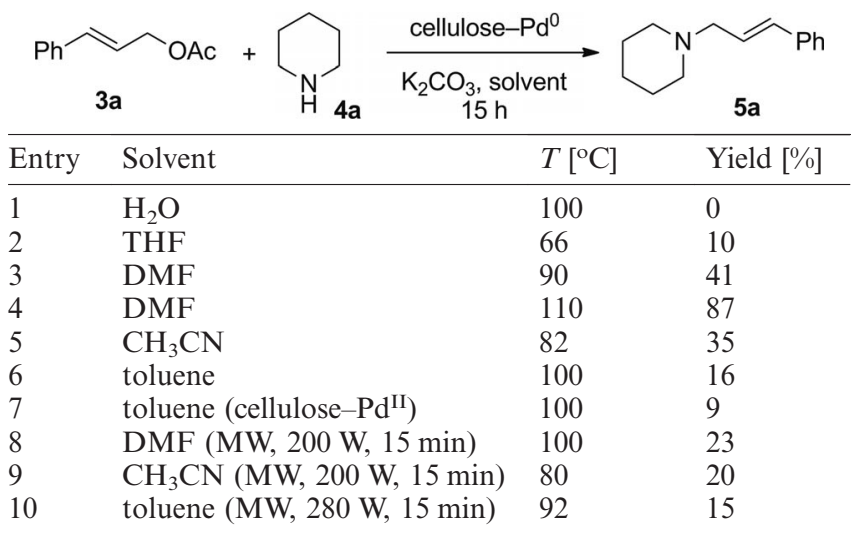

[a] Reaction conditions: Allyl acetate $(1.0 \mathrm{mmol})$, amine $(1.2 \mathrm{mmol})$, cellulose-Pd $(50 \mathrm{mg})$, and potassium carbonate $(2.0 \mathrm{mmol})$ in solvent $(3 \mathrm{~mL})$ subjected to the listed conditions.
The effect of $\mathrm{Pd}^{\mathrm{II}}$ was studied by immobilization of cellulose microcrystals on the surface by stirring a methanol suspension of cellulose and $\mathrm{PdCl}_{2}$ in an aqueous ammonia solution for $15 \mathrm{~h}$ at room temperature. When the reaction was performed with the cellulose- $\mathrm{Pd}^{\mathrm{II}}$ catalyst, a poor yield of the desired product was obtained (Table 1, entry 7). Among the various conditions explored to optimize the reaction, heating in DMF at $110^{\circ} \mathrm{C}$ for $15 \mathrm{~h}$ produced the maximum yield (Table 1, entry 4). Using these optimized conditions, the reaction was studied for its substrate scope with different amines and allylic acetates (Table 2).

The effect of various nitrogen nucleophiles was studied. The reaction of cinnamyl acetate with piperidine, morpholine, 2-methylpiperidine, benzylamine, $(S)$-methylbenzylamine, and $(R)$-methylbenzylamine resulted in products $\mathbf{5 a}-$ f (Table 2, entries 1-6) in 85-95\% yield, which indicates that the progress of the reaction is only minimally affected by structural and nucleophilicity effects. Phenylallyl acetates in which the phenyl group was substituted with activating and

Table 2. Synthesis of allylic amines catalyzed by cellulose- $\mathrm{Pd}^{0}$.

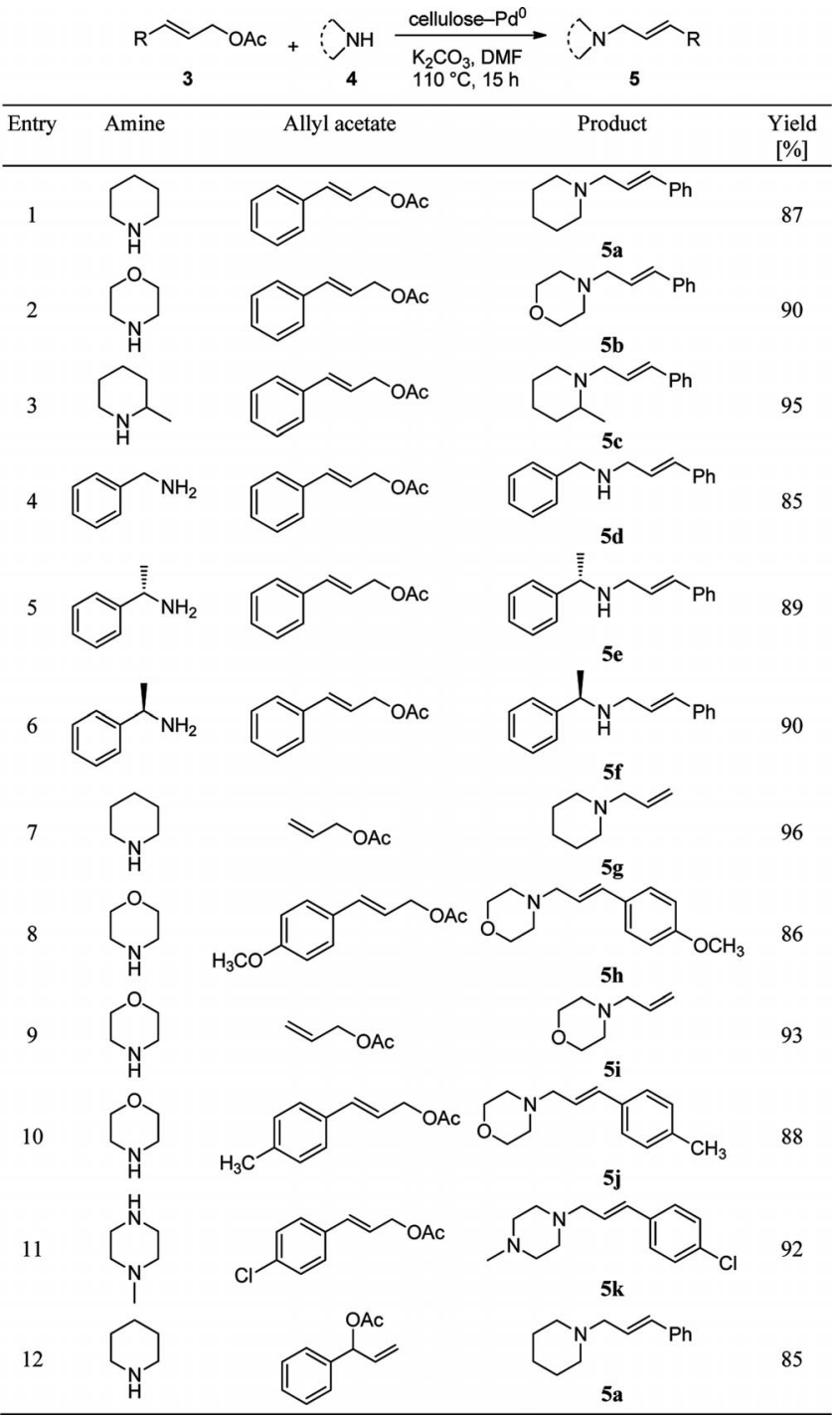


deactivating groups were employed to study the reaction scope. (E)-3-(4-Methoxyphenyl)allyl acetate participated in the reaction with morpholine to give allylated product $\mathbf{5 h}$ in $86 \%$ yield. ( $E$ )-3-(p-Tolyl)allyl acetate reacted efficiently with morpholine to afford $\mathbf{5 j}$ in $88 \%$ yield.

(E)-3-(4-Chlorophenyl)allyl acetate reacted smoothly with 1-methylpiperazine to give 5k in $92 \%$ yield. Unsubstituted allyl acetate also participated efficiently in the reaction with piperidine and morpholine to yield $\mathbf{5 g}$ and $\mathbf{5 i}$ in 96 and $93 \%$ yield, respectively, which indicates that the nature of the substituent on the allyl acetate does not have a significant effect on the reaction. A branched cinnamyl acetate, 1-phenylallyl acetate, also provided linear transproduct 5a (Table 2, entry 12), which supports the mechanism that describes the intermediacy of a $\eta^{3}$-allyl-Pd complex as the key intermediate in the reaction. The high yields of the products with various substrates indicate the broad scope of the optimized protocol. In the case of primary amines (Table 2, entries 4-6), trace amounts of diallylation products were found.

The active role of palladium in the catalytic cycle of the reaction was established by control experiments. No product formation occurred in the absence of a catalyst. The same reaction, when carried out separately in the presence of cellulose, was fruitless, but the cellulose-Pd catalyst gave good product yields, and this indicates that the reaction is catalyzed only by palladium.

Upon completion of the reaction, the catalyst was separated by filtration or centrifugation and washed with acetone followed by drying in a vacuum oven. The recovered catalyst was used over three consecutive cycles of the reaction (Table S1, Supporting Information). The amount of palladium on the cellulose was analyzed after recovering the catalyst after the fifth reaction cycle. ICP-AES analysis showed almost the same palladium concentration on the catalyst; the absence of palladium metal in the reaction solvent indicated that no metal leached into the reaction mixture. The hydroxy groups on cellulose may provide efficient binding sites that coordinate with palladium, which would thus enable efficient catalyst recycling and prevent metal leaching.

\section{Conclusions}

A simple and easy procedure for the $N$-allylation of amines was developed by using a biodegradable and easily recyclable heterogeneous cellulose-supported Pd catalyst in DMF under conventional heating. This protocol is applicable to aliphatic and benzylamines and substituted and unsubstituted allyl acetates. Highlights of this protocol include a ligand-free reaction, simple workup, and catalyst recovery and reuse.

\section{Experimental Section}

General Procedure: A mixture of allyl acetate $(1.0 \mathrm{mmol})$, amine $(1.2 \mathrm{mmol})$, cellulose-Pd $(50 \mathrm{mg})$, and potassium carbonate $(2.0 \mathrm{mmol})$ in anhydrous DMF $(3 \mathrm{~mL})$ was heated at $110^{\circ} \mathrm{C}$ under a $\mathrm{N}_{2}$ atmosphere for $15 \mathrm{~h}$. Upon completion of the reaction, as indicated by TLC, the reaction mixture was diluted with water and centrifuged/filtered to separate the catalyst. The decanted liquid was extracted with ethyl acetate $(3 \times 10 \mathrm{~mL})$; the organic layer was dried with anhydrous sodium sulfate and evaporated under reduced pressure to afford the crude product. The crude product was purified by passing through a silica gel column (ethyl acetate/hexane).

Supporting Information (see footnote on the first page of this article): Experimental procedures, ${ }^{1} \mathrm{H}$ NMR and ${ }^{13} \mathrm{C}$ NMR spectra, and MS data.

\section{Acknowledgments}

B. R. V. and A. S. are supported by the Postgraduate Research Program at the National Risk Management Research Laboratory administered by the Oak Ridge Institute for Science and Education through an interagency agreement between the U.S. Department of Energy and the U.S. Environmental Protection Agency.

[1] L. Acemoglu, J. M. J. Williams in Handbook of Organopalladium Chemistry for Organic Synthesis John Wiley \& Sons, Inc., New York, 2003, pp. 1689-1705.

[2] a) S. D. Knight, L. E. Overman, G. Pairaudeau, J. Am. Chem. Soc. 1993, 115, 9293-9294; b) S. D. Knight, L. E. Overman, G. Pairaudeau, J. Am. Chem. Soc. 1995, 117, 5776-5788.

[3] a) A. Fürstner, H. Weintritt, J. Am. Chem. Soc. 1998, 120, 2817-2825; b) A. Fürstner, T. Gastner, H. Weintritt, J. Org. Chem. 1999, 64, 2361-2366.

[4] H. Yoshizaki, H. Satoh, Y. Sato, S. Nukui, M. Shibasaki, M. Mori, J. Org. Chem. 1995, 60, 2016-2021.

[5] B. M. Trost, C. Pissot-Soldermann, I. Chen, G. M. Schroeder, J. Am. Chem. Soc. 2004, 126, 4480-4481.

[6] a) B. M. Trost, M. L. Crawley, Chem. Rev. 2003, 103, 29212944; b) B. M. Trost, Angew. Chem. 1989, 101, 1199-1219; Angew. Chem. Int. Ed. Engl. 1989, 28, 1173-1192; c) J. F. Bower, R. Jumnah, A. C. Williams, J. M. J. Williams, J. Chem. Soc. Perkin Trans. 1 1997, 1411-1420; d) K. Burgess, L. T. Liu, B. Pal, J. Org. Chem. 1993, 58, 4758-4763.

[7] a) J. Tsuji, H. Takahashi, M. Morikawa, Tetrahedron Lett. 1965, 6, 4387-4388; b) B. M. Trost, T. J. Fullerton, J. Am. Chem. Soc. 1973, 95, 292-294; c) B. M. Trost, D. L. Van Vranken, Chem. Rev. 1996, 96, 395-422.

[8] a) A. Azetsu, H. Koga, A. Isogai, T. Kitaoka, Catalysis 2011, 1 , 83-96; b) C. M. Cirtiu, A. F. Dunlop-Briere, A. Moores, Green Chem. 2011, 13, 288-291; c) Q. Du, Y. Li, Beilstein J. Org. Chem. 2011, 7, 378-385; d) P. Zhou, H. Wang, J. Yang, J. Tang, D. Sun, W. Tang, Ind. Eng. Chem. Res. 2012, 51, 5743-5748; e) P. Zhou, H. Wang, J. Yang, J. Tang, D. Sun, W. Tang, RSC Adv. 2012, 2, 1759-1761.

[9] a) P. Buisson, F. Quignard, Aust. J. Chem. 2002, 55, 73-78; b) F. Quignard, A. Choplin, Chem. Commun. 2001, 21-22.

[10] B. R. Vaddula, A. Saha, J. Leazer, R. S. Varma, Green Chem. 2012, 14, 2133-2136.

Received: September 18, 2012 Published Online: October 30, 2012 
Eur. J. Org. Chem. 2012 • C WILEY-VCH Verlag GmbH \& Co. KGaA, 69451 Weinheim, 2012 • ISSN 1434-193X

\section{SUPPORTING INFORMATION}

DOI: 10.1002/ejoc.201201241

Title: Tsuji-Trost $N$-Allylation with Allylic Acetates by Using a Cellulose-Palladium Catalyst

Author(s): Buchi Reddy Vaddula, Amit Saha, Rajender S. Varma, ${ }^{*}$ John Leazer*

This article is a U.S. government work, and is not subject to copyright in the United States. 


\section{Contents}

1. General Information $\quad$ S2

2. General Procedure for the catalyst preparation and $N$-allylation reaction $\quad \mathrm{S} 3$

3. Recovery and reuse of cellulose-Pd catalyst S3

4. Spectral data of the synthesized compounds S4

\section{General Information}

The reagents were obtained commercially and used without further purification. Cellulose fiber, medium, was obtained from Sigma-Aldrich. ${ }^{1} \mathrm{H}$ NMR and ${ }^{13} \mathrm{C}$ NMR spectra were recorded on a Bruker Avance $300 \mathrm{MHz}$ NMR spectrometer using TMS as the internal standard. Chemical shifts are given in parts per million $(\delta)$ and coupling constants $(J)$ in Hz. MS data was obtained on Hewlett Packard HP 5973 quadrupole Mass Selective Detector with interface for 6890 series GC. Thin-layer chromatography (TLC) was performed on silica gel 60 F254 precoated glass plates. 


\section{Experimental Procedures}

\subsection{Procedure for the catalyst preparation}

$1 \mathrm{gm}$ of cellulose fiber was dispersed well in $20 \mathrm{~mL}$ of water. $\mathrm{PdCl}_{2}(150 \mathrm{mg})$ was added in small quantities to the suspension. It was stirred at room temperature for $1 \mathrm{~h}$. $\mathrm{NaBH}_{4}$ (2.5 equiv.) was added in small quantities to the aqueous suspension and was stirred for $15 \mathrm{~h}$ at room temperature. The catalyst was centrifuged followed by washing with acetone and was dried under vacuum to obtain black colored powder catalyst.

\subsection{General procedure for the synthesis of allyl amines}

A mixture of allyl acetate $(1.0 \mathrm{mmol})$, nucleophile $(1.2 \mathrm{mmol})$, cellulose-Pd $(50 \mathrm{mg})$ and potassium carbonate $(2.0 \mathrm{mmol})$ in anhydrous DMF $(3 \mathrm{~mL})$ is heated at $110{ }^{\circ} \mathrm{C}$ under $\mathrm{N}_{2}$ atmosphere for 15 hours. Upon completion of the reaction as indicated by TLC, the reaction mixture is diluted with water and centrifuged/filtered to separate the catalyst. The decanted liquid is extracted with ethyl acetate $(3 \times 10$ $\mathrm{mL}$ ). The ethyl acetate layer is dried over anhydrous sodium sulfate and evaporated to get the crude product. The crude product is purified by passing through silica gel column eluting with ethyl acetatehexane.

\subsection{Recovery and reuse of Cellulose-Pd catalyst}

After completion of the reaction, the catalyst was separated from the reaction mixture by filteration. The catalyst was washed with acetone, dried under vacuum, and recycled for 5 consecutive reactions without any significant loss in efficiency (Table S1).

Table S1. Reuse of the cellulose-Pd catalyst.

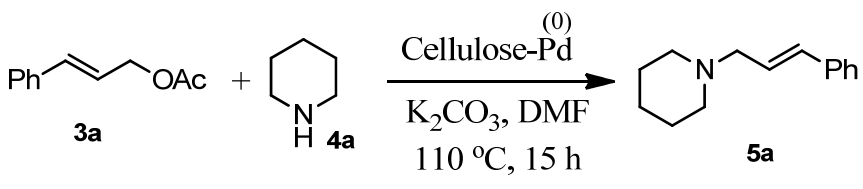

\begin{tabular}{cc}
\hline Cycle & Yield (\%) \\
\hline 1 & 87 \\
2 & 85 \\
3 & 85 \\
4 & 83 \\
5 & 82 \\
\hline
\end{tabular}




\section{${ }^{1} \mathrm{H} \&{ }^{13} \mathrm{C}$ NMR spectra}

1-Cinnamylpiperidine $(5 a)^{[1]}$<smiles>C(=C/c1ccccc1)\CN1CCCCC1</smiles>

Yield : 87\%. ${ }^{1} \mathrm{H}$ NMR (300 MHz, $\left.\mathrm{CDCl}_{3}\right) \delta 1.45$ (br s, 2H), 1.61-1.68 (m, 4H), 2.49 (m, 4H), 3.18 (dd, $J$ $=6.9 \mathrm{~Hz}$ and $6 \mathrm{~Hz}, 2 \mathrm{H}), 6.32(\mathrm{dt}, J=15.0$ and $6.9 \mathrm{~Hz}, 1 \mathrm{H}), 6.53(\mathrm{~d}, J=15.0 \mathrm{~Hz}, 1 \mathrm{H}), 7.20-7.26(\mathrm{~m}, 1 \mathrm{H})$, 7.35-7.28 (m, 2H), 7.37-7.41 (m, 2H). $\left.{ }^{13} \mathrm{C} \mathrm{NMR} \mathrm{(75} \mathrm{MHz,} \mathrm{CDCl}_{3}\right) \delta$

24.2, 25.7, 54.4, 61.6, 126.3, 126.6, 127.4, 128.5, 133.0, 137.0. MS (EI) calcd for $\mathrm{C}_{14} \mathrm{H}_{19} \mathrm{~N}\left(\mathrm{M}^{+}\right)$ 201.1517, found 201.1.

\section{4-Cinnamylmorpholine (5b) ${ }^{[1]}$}<smiles>C(=C/c1ccccc1)\CN1CCOCC1</smiles>

Yield : 90\%. ${ }^{1} \mathrm{H}$ NMR (300 MHz, $\left.\mathrm{CDCl}_{3}\right) \delta 2.53(\mathrm{t}, J=6.0 \mathrm{~Hz}, 4 \mathrm{H}), 3.18(\mathrm{dd}, J=7.2$ and $1.2 \mathrm{~Hz}, 2 \mathrm{H})$, $3.76(\mathrm{t}, J=6.0 \mathrm{~Hz}, 4 \mathrm{H}), 6.28(\mathrm{dt}, J=15.9$ and $7.5 \mathrm{~Hz}, 1 \mathrm{H}), 6.55(\mathrm{~d}, J=15.9 \mathrm{~Hz}, 1 \mathrm{H}), 7.22-7.28(\mathrm{~m}, 1 \mathrm{H})$, 7.30-7.36 (m, 2H), 7.37-7.41 (m, 2H). ${ }^{13} \mathrm{CNMR}\left(75 \mathrm{MHz}, \mathrm{CDCl}_{3}\right) \delta$

53.7, 61.5, 67.0, 126.0, 126.3, 127.6, 128.6, 133.5, 136.8. MS (EI) calcd for $\mathrm{C}_{13} \mathrm{H}_{17} \mathrm{NO}\left(\mathrm{M}^{+}\right) 203.1310$, found 203.1 .

\section{1-Cinnamyl-2-methylpiperidine (5c)}<smiles>CC1CCCCN1C/C=C/c1ccccc1</smiles>

Yield : 95\%. ${ }^{1} \mathrm{H}$ NMR $\left(300 \mathrm{MHz}, \mathrm{CDCl}_{3}\right) \delta 1.23(\mathrm{~d}, J=6.0 \mathrm{~Hz}, 3 \mathrm{H}), 1.28-1.56(\mathrm{~m}, 2 \mathrm{H}), 1.65-1.73(\mathrm{~m}$, $4 \mathrm{H}), 2.29-2.38(\mathrm{~m}, 1 \mathrm{H}), 2.49-2.57(\mathrm{~m}, 1 \mathrm{H}), 3.03(\mathrm{dt}, J=12.0$ and $6.0 \mathrm{~Hz}, 1 \mathrm{H}), 3.27(\mathrm{dd}, J=12.0$ and 6.0 $\mathrm{Hz}, 1 \mathrm{H}), 3.64$ (ddd, $J=14.1,6.0$ and $1.5 \mathrm{~Hz}, 1 \mathrm{H}), 6.35(\mathrm{dt}, J=15.0$ and $5.85 \mathrm{~Hz}, 1 \mathrm{H}), 6.55(\mathrm{~d}, J=15.0$ $\mathrm{Hz}, 1 \mathrm{H}), 7.22-7.28(\mathrm{~m}, 1 \mathrm{H}), 7.30-7.36(\mathrm{~m}, 2 \mathrm{H}), 7.38-7.42(\mathrm{~m}, 2 \mathrm{H}) .{ }^{13} \mathrm{C} \mathrm{NMR}\left(75 \mathrm{MHz}, \mathrm{CDCl}_{3}\right)$ $\delta 18.5,23.5,25.2,33.7,51.9,56.0,56.2,124.6,126.4,127.6,128.6,134.1,136.7$. MS (EI) calcd for $\mathrm{C}_{15} \mathrm{H}_{21} \mathrm{~N}\left(\mathrm{M}^{+}\right)$215.1674, found 215.1.

\section{(E)-N-Benzyl-3-phenylprop-2-en-1-amine (5d) ${ }^{[2]}$}<smiles>C(=C/c1ccccc1)\CNCc1ccccc1</smiles>

Yield : 85\%. ${ }^{1} \mathrm{H}$ NMR (300 MHz, $\left.\mathrm{CDCl}_{3}\right) \delta 3.48(\mathrm{dd}, J=6.30$ and $1.35 \mathrm{~Hz}, 2 \mathrm{H}), 3.88(\mathrm{~s}, 2 \mathrm{H}), 6.35(\mathrm{dt}, J$ $=15.0$ and $7.20 \mathrm{~Hz}, 1 \mathrm{H}), 6.57(\mathrm{~d}, J=15 \mathrm{~Hz}, 1 \mathrm{H}), 7.22-7.42(\mathrm{~m}, 10 \mathrm{H}) .{ }^{13} \mathrm{C} \mathrm{NMR}\left(75 \mathrm{MHz}, \mathrm{CDCl}_{3}\right)$ $\delta 51.0,53.1,126.3,127.1,127.4,128.0,128.3,128.5,128.6,131.8,137.1,139.8$.

MS (EI) calcd for $\mathrm{C}_{16} \mathrm{H}_{17} \mathrm{~N}\left(\mathrm{M}^{+}\right) 223.1361$, found 223.1.

$(S, E)-3-P h e n y l-N-(1-p h e n y l e t h y l) p r o p-2-e n-1-a m i n e ~(5 e)^{[3]}$ 
<smiles>C[C@H](NC/C=C/c1ccccc1)c1ccccc1</smiles>

Yield : 89\%. ${ }^{1} \mathrm{H}$ NMR $\left(300 \mathrm{MHz}, \mathrm{CDCl}_{3}\right) \delta 1.43(\mathrm{~d}, J=6.0 \mathrm{~Hz}, 3 \mathrm{H}), 3.30(\mathrm{dt}, J=6.30$ and $1.2 \mathrm{~Hz}, 2 \mathrm{H})$, $3.89(\mathrm{dd}, J=12.0$ and $6.0 \mathrm{~Hz}, 1 \mathrm{H}), 6.31(\mathrm{dt}, J=15.0$ and $6.6 \mathrm{~Hz}, 1 \mathrm{H}), 6.50(\mathrm{~d}, J=15 \mathrm{~Hz}, 1 \mathrm{H}), 7.21-7.41$ $(\mathrm{m}, 10 \mathrm{H}) .{ }^{13} \mathrm{C}$ NMR $\left(75 \mathrm{MHz}, \mathrm{CDCl}_{3}\right) \delta 24.23,49.67,57.60,126.25,126.66$,

$126.98,127.30,128.50,128.52,128.61,131.19,137.21,145.44$. MS (EI) calcd for $\mathrm{C}_{17} \mathrm{H}_{19} \mathrm{~N}\left(\mathrm{M}^{+}\right)$ 237.1517, found 237.1.

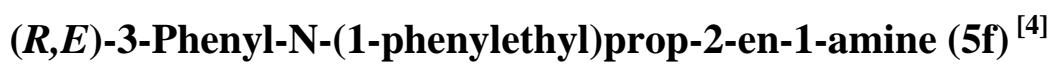<smiles>C[C@H](NC/C=C/c1ccccc1)c1ccccc1</smiles>

Yield : 90\%. ${ }^{1} \mathrm{H}$ NMR (300 MHz, $\left.\mathrm{CDCl}_{3}\right) \delta 1.43(\mathrm{~d}, J=6.0 \mathrm{~Hz}, 3 \mathrm{H}), 3.31(\mathrm{dt}, J=6.30$ and $1.2 \mathrm{~Hz}, 2 \mathrm{H})$, $3.89(\mathrm{dd}, J=12.0$ and $6.0 \mathrm{~Hz}, 1 \mathrm{H}), 6.31(\mathrm{dt}, J=15.0$ and $6.6 \mathrm{~Hz}, 1 \mathrm{H}), 6.50(\mathrm{~d}, J=15 \mathrm{~Hz}, 1 \mathrm{H}), 7.20-7.42$ $(\mathrm{m}, 10 \mathrm{H}) .{ }^{13} \mathrm{C} \mathrm{NMR}\left(75 \mathrm{MHz}, \mathrm{CDCl}_{3}\right) \delta 24.23,49.67,57.60,126.25,126.66,126.98$, 127.30, 128.50, 128.52, 128.61, 131.19, 137.21, 145.44. MS (EI) calcd for $\mathrm{C}_{17} \mathrm{H}_{19} \mathrm{~N}\left(\mathrm{M}^{+}\right) 237.1517$, found 237.1 .

\section{1-Allylpiperidine (5g) ${ }^{[5]}$}<smiles>C=CCN1CCCCC1</smiles>

Yield : 96\%. ${ }^{1} \mathrm{H}$ NMR $\left(300 \mathrm{MHz}, \mathrm{CDCl}_{3}\right): \delta 1.32-1.60(\mathrm{~m}, 6 \mathrm{H}), 2.17-2.40(\mathrm{~m}, 4 \mathrm{H}), 2.85-3.01(\mathrm{~m}, 2 \mathrm{H})$, 5.03-5.15 (m, 2H), 5.80-5.92 (m, 1H). ${ }^{13} \mathrm{C} \mathrm{NMR}\left(75 \mathrm{MHz}, \mathrm{CDCl}_{3}\right): \delta 24.4,26.0,54.3,62.7,117.7,135.5$. MS (EI) calcd for $\mathrm{C}_{8} \mathrm{H}_{15} \mathrm{~N}\left(\mathrm{M}^{+}\right)$125.1204, found 125.1 .

\section{(E)-4-(3-(4-Methoxyphenyl)allyl)morpholine (5h) ${ }^{[6]}$}<smiles>COc1ccc(/C=C/CN2CCOCC2)cc1</smiles>

Yield : 86\%. ${ }^{1} \mathrm{H}$ NMR (300 MHz, $\left.\mathrm{CDCl}_{3}\right) \delta 2.48(\mathrm{~s}, 4 \mathrm{H}), 3.12(\mathrm{~d}, J=6.5 \mathrm{~Hz}, 2 \mathrm{H}), 3.75(\mathrm{dd}, J=4.6$ and $4.5 \mathrm{~Hz}, 4 \mathrm{H}), 3.79(\mathrm{~s}, 3 \mathrm{H}), 6.12(\mathrm{dt}, J=16.0$ and $6.5 \mathrm{~Hz}, 1 \mathrm{H}), 6.48(\mathrm{~d}, J=16.0 \mathrm{~Hz}, 1 \mathrm{H}), 6.82-6.83(\mathrm{~m}$, 2H), 7.28-7.33 (m, 2H); ${ }^{13} \mathrm{C} \mathrm{NMR}\left(75 \mathrm{MHz}, \mathrm{CDCl}_{3}\right) \delta 53.5,55.2,61.4,67.0,114.0,123.5,127.4,129.5$, 132.7, 159.1. MS (EI) calcd for $\mathrm{C}_{14} \mathrm{H}_{19} \mathrm{NO}_{2}\left(\mathrm{M}^{+}\right)$233.1416, found 233.1.

\section{4-Allylmorpholine (5i) ${ }^{[5]}$}<smiles>C=CCN1CCOCC1</smiles>

Yield : 93\%. ${ }^{1} \mathrm{H}$ NMR $\left(300 \mathrm{MHz}, \mathrm{CDCl}_{3}\right): \delta 2.21-2.45(\mathrm{~m}, 4 \mathrm{H}), 2.88-3.03(\mathrm{~m}, 2 \mathrm{H}), 3.55-3.72(\mathrm{~m}, 4 \mathrm{H})$, 5.06-5.22 (m, 2H), 5.65-5.82 (m, 1H). ${ }^{13} \mathrm{C}$ NMR (75 MHz, $\left.\mathrm{CDCl}_{3}\right): \delta 53.5,62.1,67.0,118.4,134.5$. MS (EI): $\mathrm{m} / \mathrm{z}$ calcd for $\mathrm{C}_{7} \mathrm{H}_{13} \mathrm{NO}\left[\mathrm{M}^{+}\right]$: 127.0997 ; found: 127.1 .

(E)-4-(3-(p-Tolyl)allyl)morpholine (5j) $)^{[6]}$ 
<smiles>Cc1ccc(/C=C/CN2CCOCC2)cc1</smiles>

Yield : 88\%. ${ }^{1} \mathrm{H}$ NMR (300 MHz, $\left.\mathrm{CDCl}_{3}\right): \delta 2.33(\mathrm{~s}, 3 \mathrm{H}), 2.42-2.56(\mathrm{~m}, 4 \mathrm{H}), 3.10(\mathrm{dd}, J=6.6$ and 1.2 $\mathrm{Hz}, 2 \mathrm{H}), 3.68-3.73(\mathrm{~m}, 4 \mathrm{H}), 6.18(\mathrm{dt}, J=16.0$ and $6.5 \mathrm{~Hz}, 1 \mathrm{H}), 6.48(\mathrm{~d}, J=16.0 \mathrm{~Hz}, 1 \mathrm{H}), 7.10(\mathrm{~d}, J=8.0$ $\mathrm{Hz}, 2 \mathrm{H}), 7.25(\mathrm{~d}, J=8.0 \mathrm{~Hz}, 2 \mathrm{H}) .{ }^{13} \mathrm{C} \mathrm{NMR}\left(75 \mathrm{~Hz}, \mathrm{CDCl}_{3}\right): \delta=21.4,53.7,61.5,67.2,124.9,126.4$, 129.3, 133.4, 134.1, 137.5. MS (EI): $\mathrm{m} / \mathrm{z}$ calcd for $\mathrm{C}_{14} \mathrm{H}_{19} \mathrm{NO}\left[\mathrm{M}^{+}\right]: 217.1467$; found: 217.1 .

(E)-1-(3-(4-chlorophenyl)allyl)-4-methylpiperazine $(5 k)^{[7]}$<smiles>CN1CCN(C/C=C/c2ccc(Cl)cc2)CC1</smiles>

Yield : 92\%. ${ }^{1} \mathrm{H}$ NMR (300 MHz, $\left.\mathrm{CDCl}_{3}\right): \delta 2.23$ (s, 3H), 2.44 (br s, 8H), $3.11(\mathrm{~d}, J=6.5 \mathrm{~Hz}, 2 \mathrm{H}), 6.14-$ $6.23(\mathrm{~m}, 1 \mathrm{H}), 6.42(\mathrm{~d}, J=16.0 \mathrm{~Hz}, 1 \mathrm{H}), 7.14-7.25(\mathrm{~m}, 4 \mathrm{H}) ;{ }^{13} \mathrm{C} \mathrm{NMR}\left(75 \mathrm{~Hz}, \mathrm{CDCl}_{3}\right): \delta 46.2,53.3,55.2$, $60.9,127.4,127.6,128.8,131.8,133.2,135.4 ; \mathrm{MS}(\mathrm{EI}): \mathrm{m} / \mathrm{z}$ calcd for $\mathrm{C}_{14} \mathrm{H}_{19} \mathrm{ClN}_{2}\left[\mathrm{M}^{+}\right]: 250.1237$; Found: 250.1 . 
${ }^{1} \mathrm{H} \&{ }^{13} \mathrm{C}$ NMR spectra of the representative compounds

1-Cinnamylpiperidine (5a)
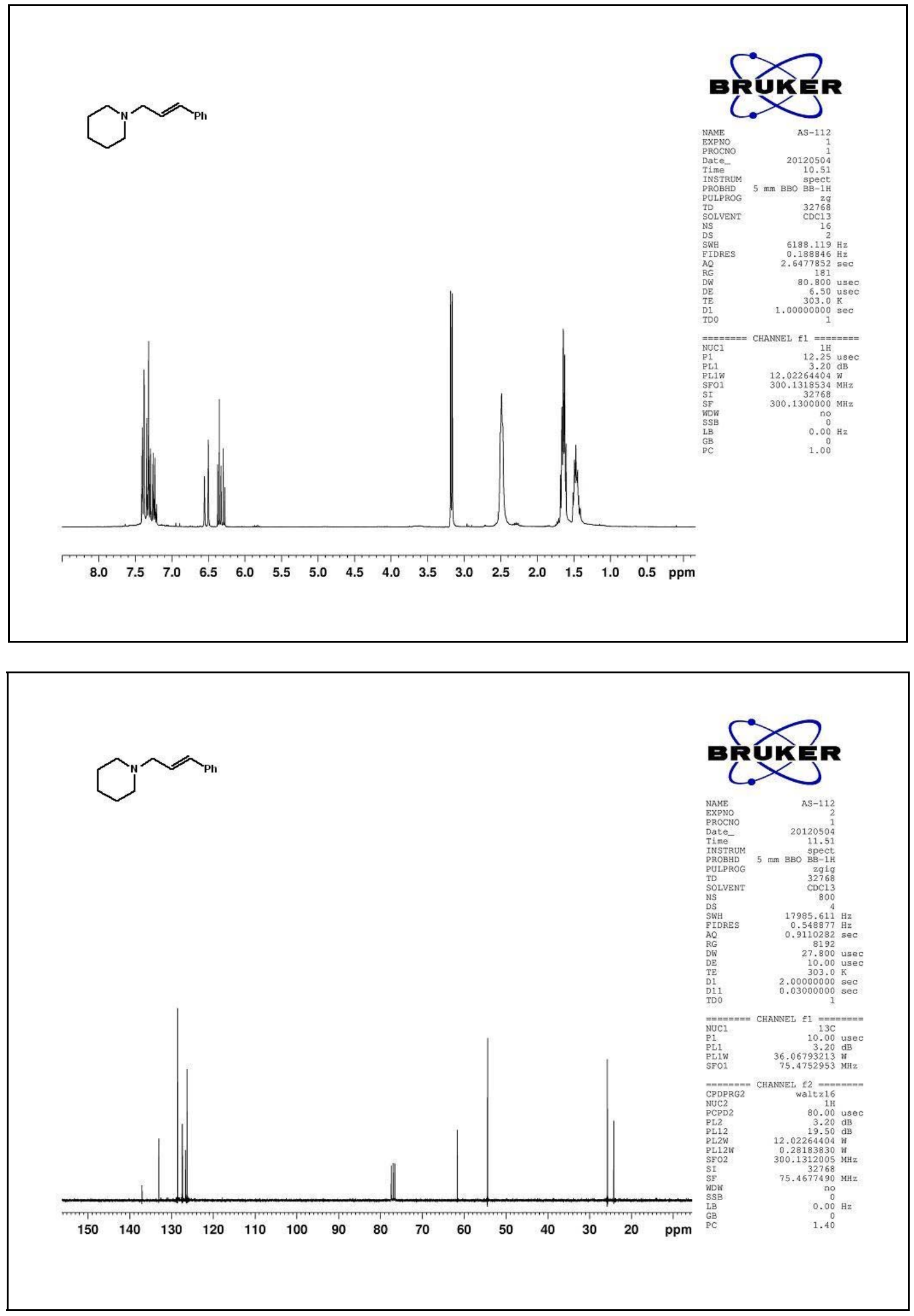


\section{4-Cinnamylmorpholine (5b)}
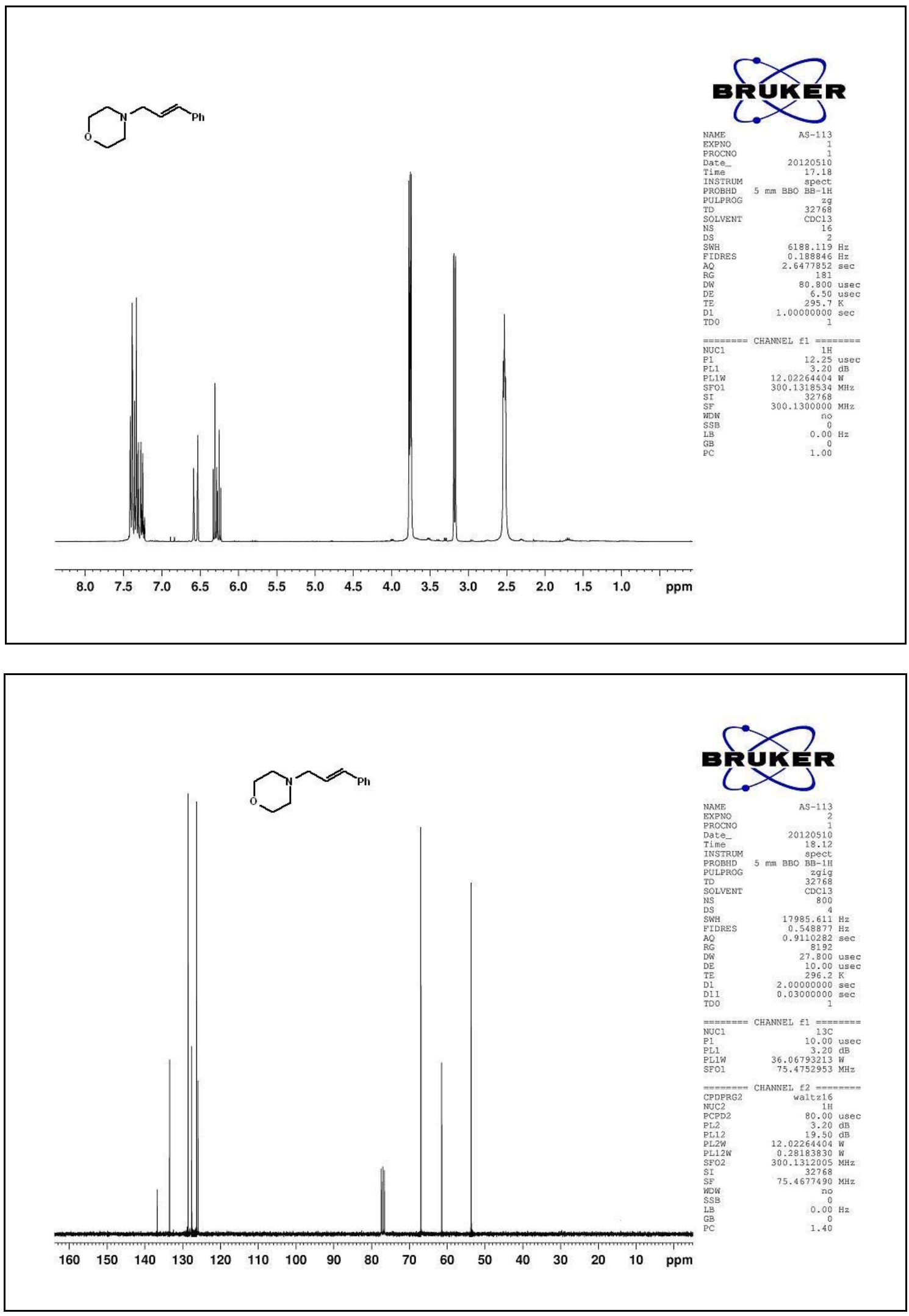


\section{1-Cinnamyl-2-methylpiperidine (5c)}
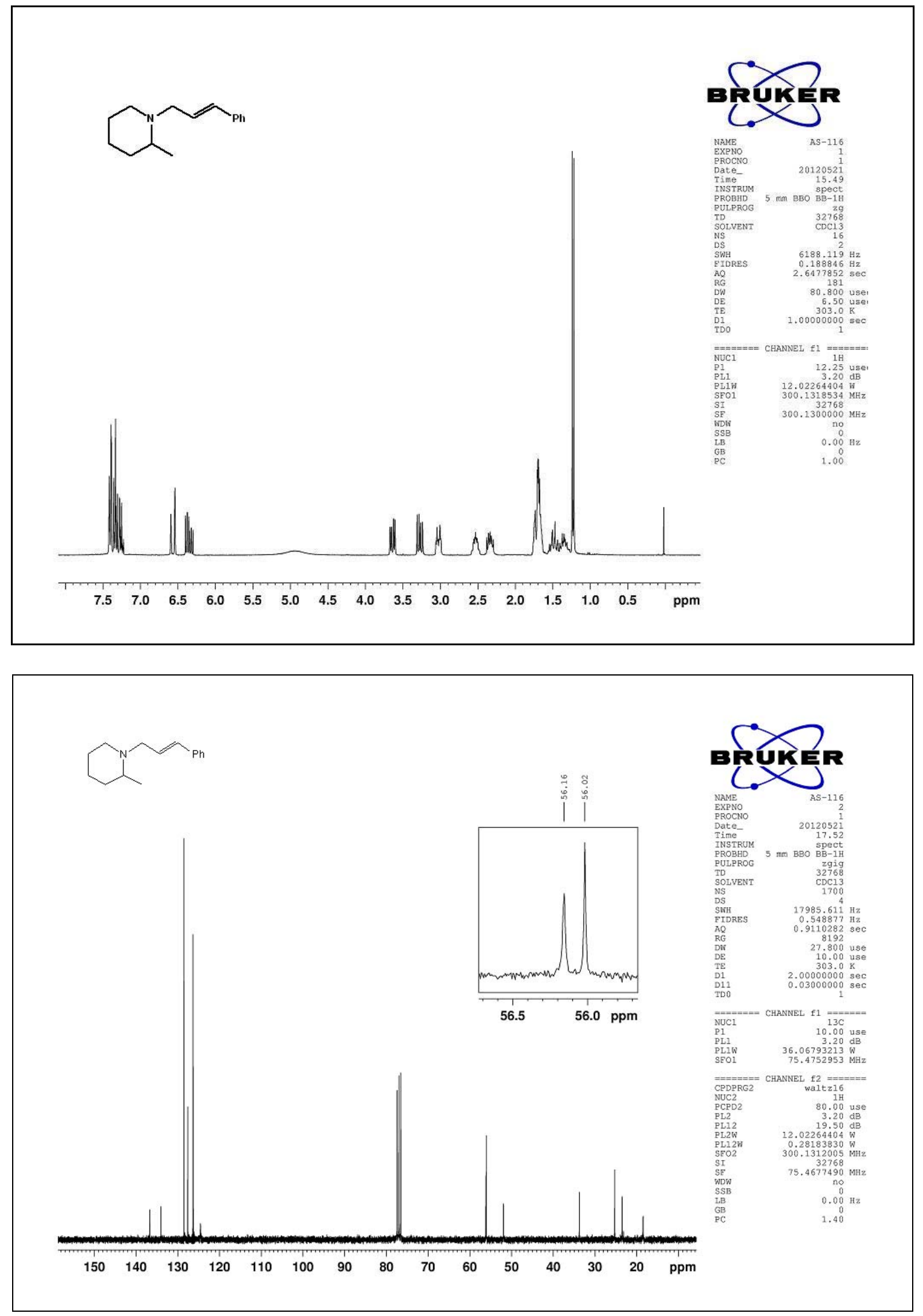
(E)-N-Benzyl-3-phenylprop-2-en-1-amine (5d)
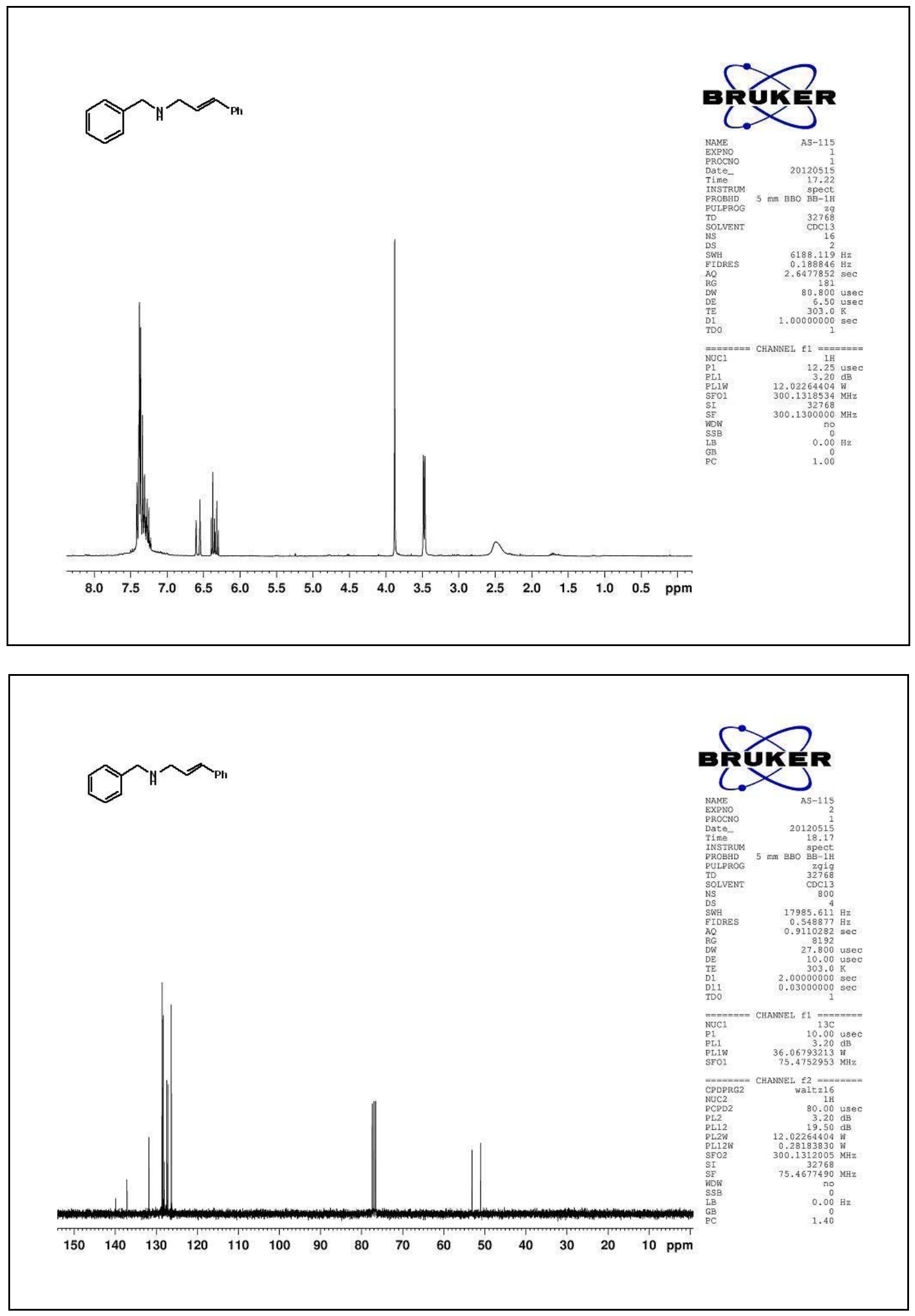

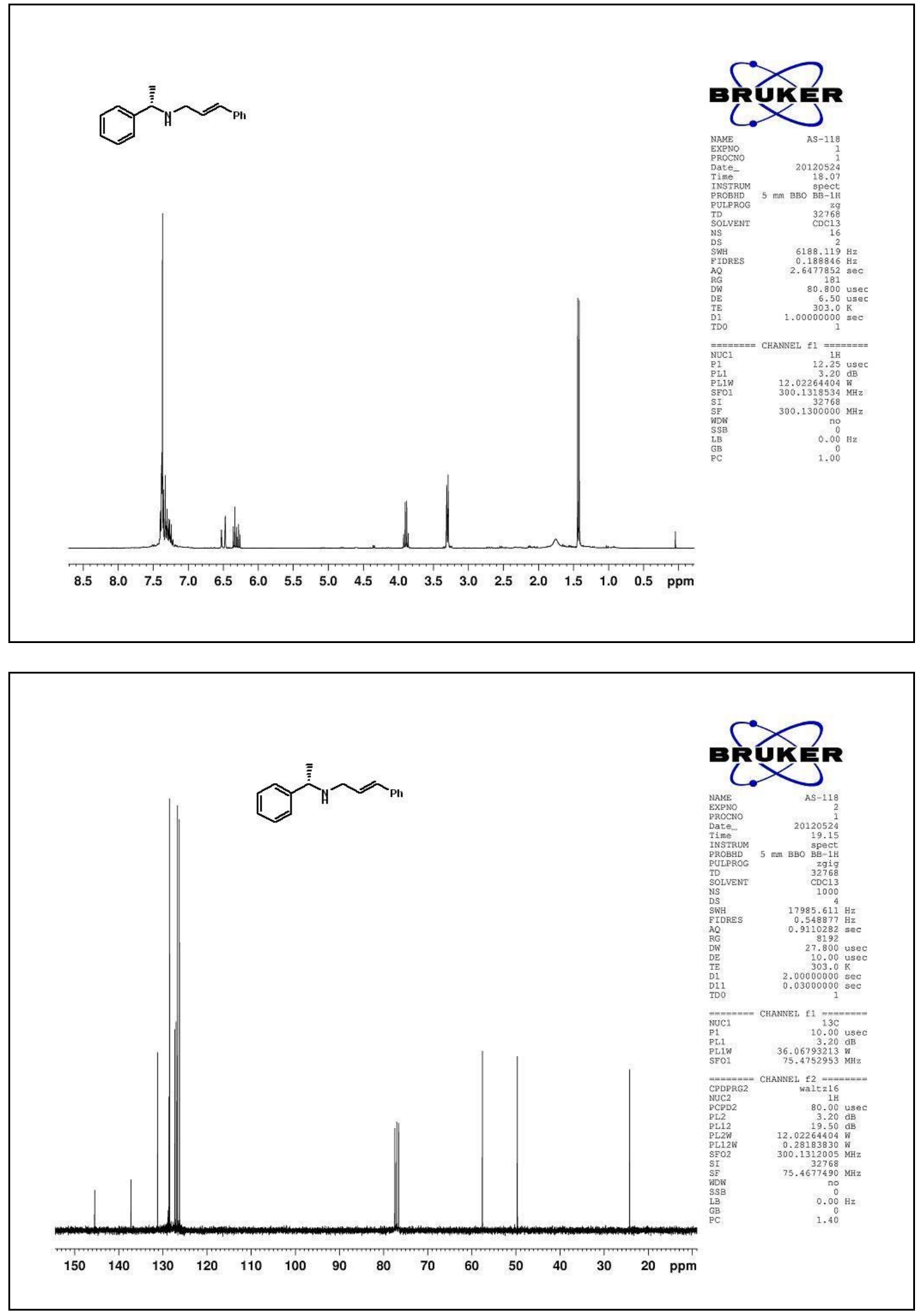


\section{References}

[1] O.-Y. Lee, K.-L. Law, C.-Y. Ho, D. Yang, J. Org. Chem. 2008, 73, 8829-8837.

[2] J. Blid, P. Brandt, P. Somfai, J. Org. Chem. 2004, 69, 3043-3049.

[3] S. G. Davies, M. E. C. Polywka, D. R. Fenwick, R. Frank, WO Patent WO/1995/018134, 1995.

[4] S. Chandrasekhar, M. V. Reddy, L. Chandraiah, Synth. Commun. 1999, 29, 3981-3987.

[5] X. Zhao, D. Liu, H. Guo, Y. Liu, W. Zhang, J. Am. Chem. Soc. 2011, 133, 19354-19357.

[6] N. Nishina, Y. Yamamoto, Synlett 2007, 1767-1770.

[7] L. Adak, K. Chattopadhyay, B. C. Ranu, J. Org. Chem. 2009, 74, 3982-3985. 